\title{
Cytomegalovirus-induced haemolytic anaemia after cardiac surgery
}

\author{
STEPHEN HOLT and NIGEL KIRKHAM \\ Liverpool Regional Cardiac Centre, Sefton General Hospital, Smithdown Road, Liverpool 15
}

\begin{abstract}
Holt, S. and Kirkham, N. (1976). Thorax, 31, 786-788. Cytomegalovirus-induced haemolytic anaemia after cardiac surgery. A patient, who underwent aortic valve replacement, developed a transient, autoimmune haemolytic anaemia in association with a significant rise in titre of antibodies against cytomegalovirus. A serological survey of blood donors indicated that the source of infection was fresh blood transfused during and shortly after surgery. A number of cases of short-lived haemolytic anaemia after large volume blood transfusion with cardiac surgery may be explained by this mechanism. It may be preferable to use only blood that has been screened for evidence of recent cytomegalovirus infection if post-perfusion complications of this disease are to be avoided.
\end{abstract}

Various mechanisms have been suggested for the pathogenesis of haemolytic anaemia after cardiac surgery. It may be the result of mechanical fragmentation of red cells (Sayed et al., 1961) or, in some cases, a delayed transfusion reaction (Boughton and Galbraith, 1975). Pirofsky et al. (1965) indicated a possible autoimmune pathogenesis in haemolytic anaemia after cardiac surgery. They suggested that turbulent flow across aortic valve prostheses may modify erythrocyte surface antigens and initiate antibody production, leading to the development of an autoimmune haemolytic anaemia. Some examples of haemolytic anaemia occurring shortly after cardiac surgery may be explained by transfused cytomegalovirus (CMV) as the following case report illustrates.

\section{CASE REPORT}

A 36-year-old housewife from Liverpool, who had undergone aortic homograft valve replacement eight years previously (Littler, 1970), was admitted with pyrexia, a normochromic, normocytic anaemia (haemoglobin $8 \mathrm{~g} / \mathrm{dl}$ ), and severe aortic incompetence. She deteriorated rapidly, sustained one cardiac arrest, and developed refractory pulmonary oedema which necessitated intermittent positive pressure ventilation.

Emergency surgery was undertaken, and at operation a necrotic homograft valve was removed and a No. 23 Björk Shiley aortic valve prosthesis was inserted. Seventeen units of fresh blood (less than 48 hours old) acquired from 17 donors were used during surgery for extracorporeal circulation and afterwards to raise her haemoglobin to 11 $\mathrm{g} / \mathrm{dl}$. In the early postoperative period she made good progress and was breathing unassisted 48 hours after surgery.

On the 27th day after operation the patient developed an acute febrile illness with a nonpruritic maculopapular rash, which began on the arms and became confluent on the upper part of the trunk. The rash faded within four days and the pyrexia subsided after two weeks. There was no hepatosplenomegaly nor lymphadenopathy. Six days after the cessation of the pyrexia (42nd postoperative day) the patient became icteric and the haemoglobin had fallen to $6.3 \mathrm{~g} / \mathrm{dl}$ with $6 \%$ reticulocytes, a white cell count of 6800 , and a 9 normal platelet count. A blood film demonstrated $\rightarrow$ a few fragmented erythrocytes and anisocytosis with normal white cell morphology. The patient's N red cells were strongly positive to the direct Coombs' test and the serum contained an auto- 0 agglutinin in high titre. This antibody was active $\omega$ at $37^{\circ} \mathrm{C}$ and $15^{\circ} \mathrm{C}$ and was shown to have anti-I specificity. Hams acid serum test, Wassermann 0 reaction, red cell fragility testing, and the Mono Spot test for heterophile antibody were all nega- $\stackrel{?}{?}$ tive. Screening, using Identigen red cell panels on the patient's serum, failed to demonstrate other $\stackrel{\vec{D}}{\mathbb{D}}$ antibodies that may have indicated a delayed transfusion reaction. 
A CMV complement fixation test showed a titre of 1 in 80 at the time of haemolysis. This was repeated two and four months after surgery when the titre had risen to 1 in 160 and 1 in 1280, indicating recent $\mathrm{CMV}$ infection. Attempted virus isolation from the patient's urine, throat swab, and buffy coat was unsuccessful, and CMV inclusion bodies could not be demonstrated in the urine deposit. The haemolytic anaemia recovered spontaneously over a period of three weeks and the patient was discharged from hospital 10 weeks after operation with a haemoglobin of $10 \mathrm{~g} / \mathrm{dl}, 1 \%$ reticulocytes, and a normal blood film.

DONOR TRACING WITH RESULTS The findings in this patient prompted a search for the source of CMV infection. The 17 blood donors were traced, medical histories were obtained, and their sera were tested for CMV antibody. Four donors were identified with CMV titres greater than 1 in 40 . One of them, a young housewife, had a rising CMV titre from 1 in 320 to 1 in 1260 , suggesting recent CMV infection. Her family, consisting of three children and her husband, were screened for CMV antibody. Her husband's serum demonstrated a titre of 1 in 320 against CMV antigen. The children's sera did not demonstrate significant titres of antibody. Virus isolation was attempted from the donors without success. All donors denied any recent illness.

\section{DISCUSSION}

Cytomegalovirus infection acquired by blood transfusion may produce an acute infectious mononucleosis-like syndrome (Kääriäinen, Klemola, and Paloheimo, 1966) and an interstitial pneumonitis (Henson, 1967). This organism has been implicated as a cause of acquired haemolytic anaemia in children (Zuelzer et al., 1966) and one adult (Coombs, 1968). It therefore seems likely that transfused CMV could result in a postperfusion haemolytic anaemia although this has not previously been reported. We believe that this occurred in our patient.

Subclinical cytomegaloviraemia is present in at least $5 \%$ of blood donors (Diosi, Moldovan, and Tomescu, 1969), and in patients receiving blood from multiple donors a significant percentage may acquire CMV, especially if fresh blood is used. In the case of cardiac surgery requiring large volume transfusion derived from many donors, up to $60 \%$ of patients who are seronegative preoperatively will acquire CMV antibodies (Stern, 1975). Seroconversion to $\mathrm{CMV}$ antigen in 21 out of 55 patients subjected to open-heart surgery with bypass was reported by Caul et al. (1971). Only seven of these patients developed the postperfusion syndrome, indicating that, despite the development of antibodies, clinical sequelae are infrequent.

A number of attempts have been made to isolate CMV in the donor blood transfused to patients who show seroconversion against CMV antigen. A survey of Bristol donors (Perham et al., 1971) demonstrated CMV antibody in $55 \%$ of 195 donors, but, as in our study, virus was not isolated from throat swab, fresh blood or urine of any donor. Convincing evidence that primary infection or reinfection with a different serotype of CMV may occur from blood transfusion was presented by Lang and Hanshaw (1968) when the virus was cultured from the urine and leucocytes of patients with the postperfusion syndrome. The 30-day interval between transfusion and the onset of our patient's illness corresponds with the mean time interval of 27 days reported by Kääriäinen $e t$ al. (1966) for the development of posttransfusion CMV mononucleosis. Also, if CMV antibody is slow to develop and persistent, as in our patient, then this is suggestive of a de novo infection (Hanshaw, Steinfeld, and White, 1968). The timing and nature of antibody response in this patient and in at least one of her blood donors is in favour of a haematogenous route of CMV transmission.

It could be argued that the association of recent CMV infection and the haemolytic anaemia was merely coincidental. Certain viral and mycoplasma infections are well recognized causes of haemolytic anaemia in which autoagglutinins may be demonstrated (Worlledge and Blajchman, 1972). Furthermore, evidence has emerged that CMV infection may stimulate the formation of autoimmune phenomena, such as rheumatoid factor, antinuclear factor, cold agglutinins, and positive direct antiglobulin tests (Kantor et al., 1970). The occurrence of a febrile illness with a short-lived haemolytic process, and the demonstration of an autoagglutinin coincidental with a rise in antibody titre against CMV antigen, suggests that CMV may have incited the haemolytic process in our patient.

Data have accumulated indicating a strong relationship between transfusion volume and seroconversion risk (Prince et al., 1971). Because large volume blood transfusion is often required for open-heart surgery, the finding of haemolytic anaemia due to transfused CMV has important practical implications. Though transmission of the 
organism is more likely in patients receiving fresh blood, a significant incidence of primary type seroconversion against CMV antigen is also experienced when stored blood (greater than 3 days old) is used (Prince et al., 1971). The finding of acquired haemolytic anaemia occurring as a result of transfused CMV is a further reason to advocate that blood used during cardiac surgery is obtained from donors who are seronegative against CMV antigen.

We are grateful to Dr. C. S. McKendrick for permission to publish, to Dr. G. B. White for performing the virological investigations, and to Dr. D. Lehane for help with donor tracing.

\section{REFERENCES}

Boughton, B. J. and Galbraith, P. R. (1975). Isoimmune haemolysis in pathogenesis of anaemia after cardiac surgery. British Medical Journal, 4, 430.

Caul, E. O., Clarke, S. K. R., Mott, M. G., Perham, T. G. M., and Wilson, R. S. E. (1971). Cytomegalovirus infections after open heart surgery: a prospective study. Lancet, 1, 777.

Coombs, R. R. H. (1968). Cytomegalic inclusionbody disease associated with acquired autoimmune haemolytic anaemia. British Medical Journal, 2, 743.

Diosi, P., Moldovan, E., and Tomescu, N. (1969). Latent cytomegalovirus infection in blood donors. British Medical Journal, 4, 660.

Hanshaw, J. B., Steinfeld, H. J., and White, C. J. (1968). Fluorescent-antibody test for cytomegalovirus macroglobulin. New England Journal of Medicine, 279, 566.

Henson, D. (1967). Cytomegalic Inclusion disease following multiple blood transfusions. Journal of the American Medical Association, 199, 278.

Kääriäinen, L., Klemola, E., and Paloheimo, J. (1966). Rise of cytomegalovirus antibodies in an infec- tious mononucleosis-like syndrome after transfusion. British Medical Journal, 1, 1270.

Kantor, G. L., Goldberg, L. S., Johnson, B. L. Jr., Derechin, M. M., and Barnett, E. V. (1970). Immunologic abnormalities induced by postper- $\triangle$ fusion cytomegalovirus infection. Annals of Internal Medicine, 73, 553.

Lang, J. D. and Hanshaw, J. B. (1968). Cytomegalo- $\vec{\circ}$ virus infection and the post perfusion syndrome. New England Journal of Medicine, 280, 1145.

Littler, W. A. (1970). Successful pregnancy in a patient with a homograft aortic valve. British $\vec{x}$ Heart Journal, 32, 416.

Perham, T. G. M., Caul, E. O., Conway, P. J., and $\vec{\sigma}$ Mott, M. G. (1971). Cytomegalovirus infection in blood donors-a prospective study. British Journal of Haematology, 20, 307.

Pirofsky, B., Sutherland, D. W., Starr, A., and Griswold, H. E. (1965). Hemolytic anemia complicating aortic-valve surgery. New England Journal of Medicine, 272, 235.

Prince, A. M., Szmuness, W., Millian, S. J., and David, D. S. (1971). A serologic study of cytomegalovirus infections associated with blood transfusions. New England Journal of Medicine, 284, 1125.

Sayed, H. M., Dacie, J. V., Handley, D. A., Lewis, S. M., and Cleland, W. P. (1961). Haemolytic anaemia of mechanical origin after open heart surgery. Thorax, 16, 356.

Stern, H. (1975). Cytomegalovirus infection. British Journal of Clinical Practice, 29, 245.

Worlledge, S. M. and Blajchman, M. A. (1972). The autoimmune haemolytic anaemias. British Journal of Haematology, 23 (Suppl.), 61.

Zuelzer, W. W., Stulberg, C. S., Page, R. H., Teruya, J. and Brough, A. J. (1966). Etiology and pathogenesis of acquired hemolytic anemia. Transfusion (Philadelphia), 6, 438.

Requests for reprints to: Dr. S. Holt, Liverpool Regional Cardiac Centre, Sefton General Hospital, Smithdown Road, Liverpool 15. 